\title{
Regional, watershed, and site-specific environmental influences on fish assemblage structure and function in western Lake Superior tributaries
}

\author{
John C. Brazner, Danny K. Tanner, Naomi E. Detenbeck, Sharon L. Batterman, \\ Stacey L. Stark, Leslie A. Jagger, and Virginia M. Snarski
}

\begin{abstract}
The relative importance of regional, watershed, and in-stream environmental factors on fish assemblage structure and function was investigated in western Lake Superior tributaries. We selected 48 second- and third-order watersheds from two hydrogeomorphic regions to examine fish assemblage response to differences in forest fragmentation, watershed storage, and a number of other watershed, riparian, and in-stream habitat conditions. Although a variety of regional, fragmentation, and storage-related factors had significant influences on the fish assemblages, water temperature appeared to be the single most important environmental factor. We found lower water temperatures and troutsculpin assemblages at lower fragmentation sites and higher temperatures and minnow-sucker-darter assemblages as storage increased. Factors related to riparian shading and flow separated brook trout streams from brown trout (Salmo trutta) - rainbow trout (Oncorhynchus mykiss) streams. Functionally, fish assemblages at lower fragmentation sites were dominated by cold-water fishes that had low silt tolerance and preferred moderate current speeds, while fishes with higher silt tolerances, warmer temperature preferences, and weaker sustained swimming capabilities were most common at higher storage sites. Our results suggest that site-specific environmental conditions are highly dependent on regional- and watershed-scale characters and that a combination of these factors operates in concert to influence the structure and function of stream fish assemblages.
\end{abstract}

Résumé : Nous avons déterminé l'importance relative des facteurs environnementaux de la région, du bassin versant et du cours d'eau lui-même sur la structure et le fonctionnement de communautés de poissons dans des tributaires de la région occidentale du lac Supérieur. Nous avons choisi 48 bassins versants d'ordres 2 et 3 dans deux régions hydrogéomorphologiques afin d'étudier la réponse des communautés de poissons à des différences de fragmentation des forêts, de rétention des bassins versants et de plusieurs autres conditions de l'habitat reliées au bassin versant, à la rive et au cours d'eau. Bien que plusieurs facteurs associés à la région, à la fragmentation et à la rétention aient une influence significative sur les communautés de poissons, la température semble être le facteur environnemental unique le plus important. Dans les sites de fragmentation réduite, les températures de l'eau sont plus basses et la communauté de salmonidés et de chabots prédomine, alors que lorsque la rétention augmente, les températures sont plus élevées et la communauté de ménés, de meuniers et de dards domine. Les facteurs reliés à l'ombrage des rives et au débit permettent de séparer les cours d'eau à ombles de fontaines des cours d'eau à truites brunes (Salmo trutta) et arc-en-ciel (Oncorhynchus mykiss). Dans les sites de fragmentation plus faible, la communauté de poissons est dominée fonctionnellement par des poissons d'eau froide, à faible tolérance de l'envasement et avec une préférence pour les courants moyens, alors que les poissons qui tolèrent plus l'envasement, qui préfèrent les eaux plus chaudes et qui possèdent des capacités de nage soutenue plus faibles se retrouvent plus communément dans des sites de rétention plus grande. Nos résultats indiquent que les conditions du milieu reliées au site dépendent fortement des caractéristiques qui existent aux échelles de la région et du bassin versant et qu'une combinaison de ces facteurs agissent de concert pour affecter la structure et le fonctionnement des communautés de poissons d'eau courante.

[Traduit par la Rédaction]

Received 27 January 2004. Accepted 17 December 2004. Published on the NRC Research Press Web site at http://cjfas.nrc.ca on 10 June 2005.

J17939

J.C. Brazner, ${ }^{1,2}$ D.K. Tanner, N.E. Detenbeck, S.L. Batterman, and V.M. Snarski. US Environmental Protection Agency, Office of Research and Development, National Health and Environmental Effects Research Laboratory, Mid-Continent Ecology Division, 6201 Congdon Boulevard, Duluth, MN 55804, USA.

S.L. Stark. Department of Geography, University of Minnesota-Duluth, Duluth, MN 55812, USA.

L.A. Jagger. US Forest Service, Olympia Forestry Sciences Laboratory, Olympia, WA 985124, USA.

${ }^{1}$ Corresponding author (e-mail: johnbrazner@eastlink.ca).

${ }^{2}$ Present address: 29 Powers Drive, Herring Cove, NS B3V 1G6, Canada. 


\section{Introduction}

Ecological linkages among landscape features, in-stream habitat, and fish assemblages have not been as thoroughly examined as direct relationships between fish and their instream habitats (Gorman and Karr 1978; Angermeier and Schlosser 1989). However, studies on the role of landscapescale processes (Sharma and Hilborn 2001; Wiley et al. 2002) have led to an improved understanding of the impacts of watershed disturbances across a wide range of spatial scales that influence biotic assemblages (Angermeier and Winston 1999; Schlieger 2000; Wang et al. 2003). One of the primary landscape disturbances in the northern Great Lakes region continues to be logging and land-clearing activities (Johnston 1990). In fact, logging and land clearing have been one of the most significant sources of stress to aquatic ecosystems of the northern Great Lakes for almost two centuries (Government of Canada and US Environmental Protection Agency 1995), and nearly all watersheds in the Lake Superior region were clearcut at least once in the last 125 years (Albert 1995). The effects of logging and associated forest fragmentation on salmonid fishes and their instream habitats have been intensively studied in the Pacific Northwest (see Murphy (1995) and Spence et al. (1996) for reviews) but virtually ignored in the midwest. Impacts on western salmonids have been observed; however, responses have not been unequivocal and vary with harvest type (Bisson and Sedell 1984; Hartman et al. 1996). Because of the complexity of these responses in the west, a paucity of data from the midwest, and regional differences in driving climatic factors that may constrain fish assemblages, we examined the ecological impacts of forest fragmentation on fishes in western Lake Superior tributaries. By moving beyond the primarily single population focus taken in the west, we hoped to provide a more holistic view of this issue.

As part of a comparative watershed project in the western basin of Lake Superior, we assessed the vulnerability of streams to landscape disturbance. The overall goal of the broader study (Detenbeck et al. 2000) was to examine differences in hydrology, water quality, and in-stream biotic communities across landscapes with varying conditions of watershed storage capacity and anthropogenic disturbance. Predictions based on a conceptual model were that nutrient and sediment loading, runoff, and stream temperature would increase at higher watershed fragmentation levels (Detenbeck et al. 2000) and that the distribution and quantity of wetlands and lakes in watersheds would mediate some forest fragmentation effects by retaining or processing nutrients, moderating peak flows, and stabilizing baseflow periods (Johnston et al. 1990; Detenbeck et al. 1993). We had three main objectives in this paper: $(i)$ to determine the relative influence of hydrogeomorphic region, forest fragmentation, watershed storage, and in-stream habitat on fish assemblages in western Lake Superior tributaries, (ii) to gain a better understanding of the interrelationships among landscape and in-stream variables, and (iii) to identify which structural and functional characters of the fish assemblages were most indicative of particular environmental conditions associated with our landscape treatments. In a closely related paper (Brazner et al. 2004), we built predictive models that characterized direct linkages between landscape features and fish assem- blage characteristics and estimated thresholds in landscape features where dramatic shifts in biotic assemblages were likely to occur. Our focus here is on interrelationships across spatial scales rather than direct linkages per se.

We used both a taxonomic approach and a functional approach to analyze our fish assemblage data because we felt that a functional perspective would provide a more comparable characterization of assemblage response to environmental gradients when assemblages were naturally dissimilar in taxonomy owing to large geographic separation (Keddy 1992; Poff 1997). Our specific expectations about fish assemblage responses were as follows: $(i)$ trophic and habitat generalists with warmer water temperature preferences, high silt tolerances, smaller, streamlined body types, and opportunistic spawning strategies that do not require gravel-cobble substrates would be associated with more fragmented watersheds (Schlosser 1982, 1990; Poff and Allan 1995), (ii) salmonid species would dominate at colder, less fragmented streams (Barton et al. 1985; Steedman 1988), and (iii) cyprinid species would dominate at warmer, more fragmented streams and in streams with higher watershed storage (Lyons 1992a; Wang et al. 1997). Because our watersheds included several ecological units with different geomorphologies, vegetation, and climate (Albert 1995), we also anticipated regional differences in biotic responses (Hughes et al. 1987; Wiley et al. 1997) to differences in fragmentation and storage.

\section{Materials and methods}

\section{Study area}

Our study was completed within $160 \mathrm{~km}$ of Duluth, Minnesota, in the Northern Lakes and Forests Ecoregion (Omernik and Gallant 1988) but may be better defined by the US Forest Service ecological unit system (Maxwell et al. 1995), which is based on finer differences in geomorphology, soils, and climate within this ecoregion (Fig. 1). We focused our watershed selection primarily within two ecological units, the North Shore Highlands (north shore streams) and the Lake Superior Clay Plain (south shore streams) (Keys et al. 1995), which provided an excellent contrast in hydrogeomorphic types.

The North Shore Highlands are typified by steeper, rockier, more flashy streams and relatively small watersheds, while streams in the Lake Superior Clay Plain are typically low-gradient, meandering systems with sand and clay soils that contribute to high suspended sediment loads. Wetlands are more common in the headwaters than in the steep, rocky lower reaches of north shore rivers, in contrast with the south shore where wetlands are common in lower stream reaches because of the low gradients. There is more agriculture in south shore watersheds than along the north shore and forestry operations throughout the region. The presettlement forests of both of these areas were dominated by mixed hardwood-pine forests. In the Clay Plain of Wisconsin, balsam fir, white spruce, and sugar maple were the dominant species, but now, trembling aspen dominates with only remnants of the presettlement conifers and hardwoods remaining. In the North Shore Highlands, white pine - red pine, aspen-birch, and mixed hardwood-pine were the dominant presettlement forests, but now, trembling aspen dominate 
Fig. 1. Map of the comparative watershed study area and its relative position in the Great Lakes.

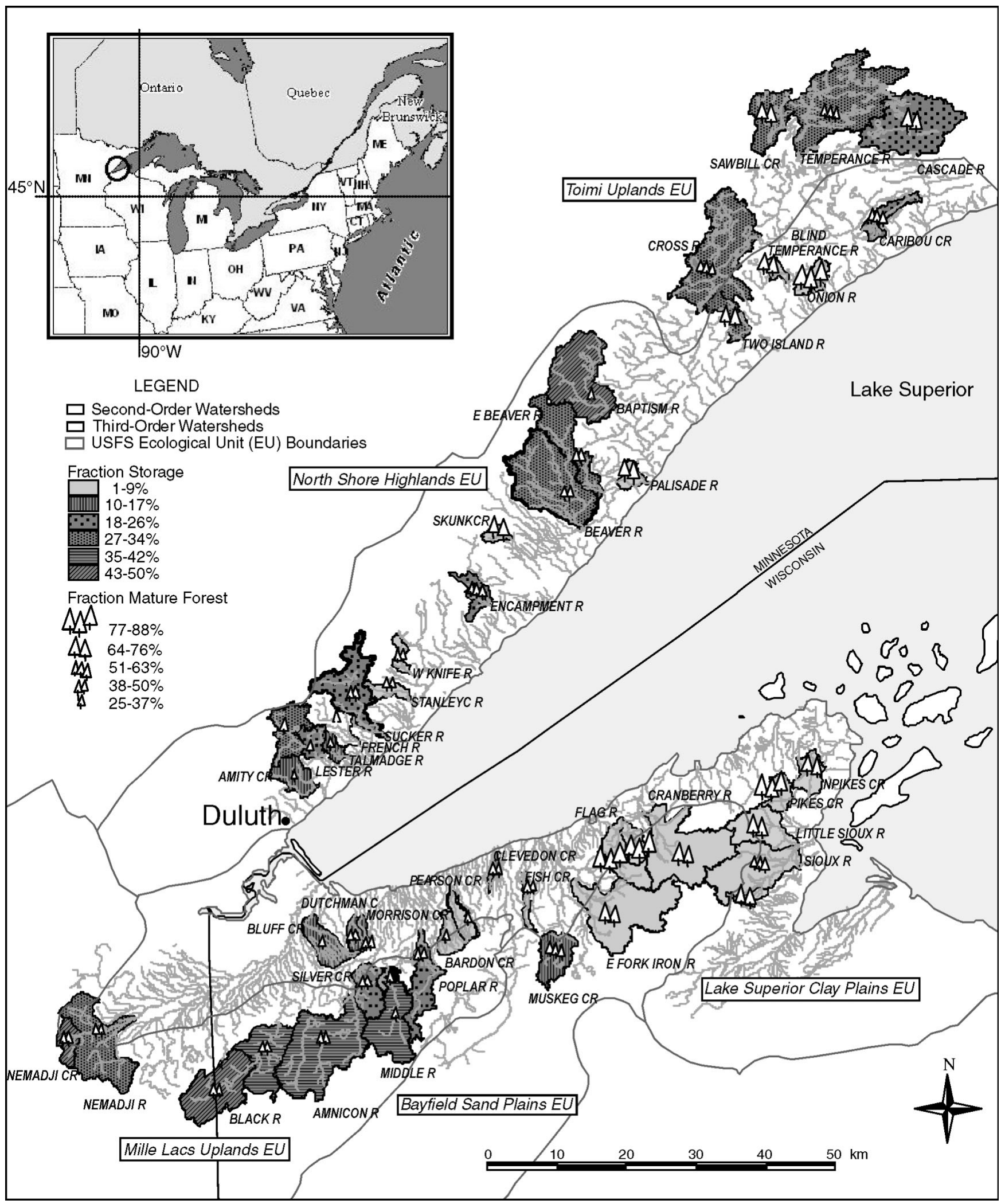

and balsam fir, white birch, and white spruce are common (Albert 1995).

Our method for describing the population of potential second- and third-order-study watersheds from within these two hydrogeomorphic regions using digital geographic data has been described in detail (Detenbeck et al. 2000). All second- $(n=362)$ and third-order $(n=90)$ watersheds in each region within the study area were characterized for 
size, gradient, percent mature forest (>15-year-old stands based on the classification of Wolter et al. (1995)), area recently logged (within the last 15 years based on the classification of Verry (1986)), and storage (total wetland and lake area). Initial selection of 24 second-order and 24 third-order watersheds was a random draw from within the entire population of watersheds to provide a balanced factorial design for two levels of each treatment factor (north versus south hydrogeomorphic region, high versus low mature forest, as a surrogate for forest fragmentation, and low versus high watershed storage) based on estimates from the initial geographic information system (GIS) characterizations of the entire watersheds. Experimental thresholds (50\% mature forest, $10 \%$ storage) were selected based on hydrologic thresholds related to forest (Verry 1986) and wetland (Hey and Wickencamp 1996) cover established empirically for midwest watersheds. Since the range of watershed storage was quite limited for third-order streams along the north shore, we made an a priori decision to select more south (14) than north shore (10) third-order watersheds to maximize the gradient of storage conditions included. The limited range of storage conditions represented on the north shore obviously limits our ability to draw conclusions about low storage sites on that shore, but since truly low storage watersheds do not occur on the north shore, the problem does not seem particularly important. Nevertheless, readers should keep in mind that owing to these natural landscape constraints, effects related to low storage were derived primarily from changes detected at south shore sites, especially for third-order streams.

\section{In-stream monitoring: physical-chemical conditions}

We relied heavily on the habitat evaluation methods and the rationale described by Simonson et al. $(1994 a, 1994 b)$ to develop our habitat sampling procedures. We selected habitat and water quality measurements for their potential to influence fish assemblages or reflect watershed conditions. Habitat variables were measured once during August at or near baseflow conditions along a stream reach length of approximately 35 mean stream widths. Habitat and water quality were assessed in 1997 in second-order streams and in 1998 in third-order streams.

Reaches were selected that had in-stream physical habitat, bank vegetation, and land-use characteristics representative of the stream segment of interest based on field reconnaissance of reaches at all possible access points prior to final site selection. We felt that this would help assure that results applied more broadly than simply to the specific reach sampled. Lack of landowner permission and stream inaccessibility limited our ability to do to complete reach assessments for a few streams, but this was generally not a problem. Where sampling reaches were immediately adjacent to road crossings, we selected reaches upstream from the crossing whenever landowner permission allowed. Reaches with permanent tributaries or hydraulic controls (e.g., dams, bridge abutments, and waterfalls) were avoided, as were portions of the stream within 10 mean stream widths of any of these features. Minimum reach length was $150 \mathrm{~m}$ and maximum length was $500 \mathrm{~m}$ following the rationale of Meador et al. (1993a). A random sequence of sampling across all sites was used to minimize potential seasonality effects.
Habitat variables were measured along 13 equally spaced transects per reach, perpendicular to stream flow, as described by Platts et al. (1983) and modified by Simonson et al. $(1994 a)$. Stream habitat characteristics were measured at either a transect-reach scale (1 mean stream width above and below the transect), a transect-line scale (length or distance of a character along the transect), or at quadrat points $(0.3 \mathrm{~m} \times$ $0.3 \mathrm{~m}$ ) along the transect lines or based on maps of habitat units made during initial site inspections (Simonson et al. $1994 a$ ).

Of the 50 in-stream habitat variables that we measured (Appendix A), only a few are not described in Simonson et al. (1994a, 1994b). Most are self-explanatory, but a few need further detail. Fish cover was defined as habitat features that were at least $0.2 \mathrm{~m}^{3}$ in volume in or within $0.1 \mathrm{~m}$ of water that is $0.05 \mathrm{~m}$ deep. We reduced the volume suggested by Simonson et al. (1994b) to better reflect habitat for both game (e.g., trout) and nongame fishes (e.g., minnows). Riparian land use was evaluated within $10 \mathrm{~m}$ of the stream (instead of $5 \mathrm{~m}$ ) on both banks, and riparian buffer width was estimated to within $30 \mathrm{~m}$ (increased from $10 \mathrm{~m}$ ). Percent shading in the riparian and percent riparian conifers were visually estimated within $30 \mathrm{~m}$ of the stream. The 1- to 3-year floodplain was estimated to a maximum of $50 \mathrm{~m}$ along each bank and canopy angle was measured as described in Meador et al. (1993b). Habitat complexity was estimated as the total time fished in a reach standardized by the area sampled, since all habitats were fished in a reach and more complex habitats required more time to fish thoroughly.

Water quality conditions (Appendix A) were assessed with a variety of methods. Conductivity and dissolved oxygen were measured with Hydrolab Data Sonde III surveyor probes (Hydrolab Corp., Austin, Texas) in situ, and $\mathrm{pH}$ and turbidity were analyzed in the laboratory as described in Detenbeck et al. (1997). Samples were collected monthly during baseflow conditions (Detenbeck et al. 1997). All water quality variables were summarized as mean, maximum, and minimum values observed during all sampling periods. Water temperature was recorded every $15 \mathrm{~min}$ from May through October using temperature loggers mounted in pools within $5 \mathrm{~cm}$ of the bottom near the middle of each reach (Optic StowAway) (Onset Corp., Pocasset, Massachusetts). Because we were not certain which temporal scale would be most critical for water temperature, it was summarized as 7-, 21-, and 28-day average maximums of continuously logged temperatures and 1-day average maximums. The 1-day average maximum represents the one day during our study with the highest average temperature across the whole day. Maximum averages represent 7- to 28-day periods with the highest average of daily maximum temperatures based on calculations of all possible periods of 7,21 , and 28 days during the study.

\section{Watershed variables}

Watershed area, channel gradient, percentage of watershed in mature forest, percent recently logged ( $\leq 15$ years), and percent lake and wetland cover (Appendix A; Brazner et al. 2002), were quantified using ARC/INFO software (version 7.2) (ESRI, Redlands, California) from GIS data obtained from a variety of sources (Detenbeck et al. 2000). Mature forest cover was quantified as $>15$-year-old stands using the 
GIS developed by Wolter et al. (1995) from late 1980s Thematic Mapper and Multi-Spectral Scanner satellite imagery. We selected 15 years as our mature forest - recently logged threshold to remain comparable with Verry's (1986) forest classifications for this region. Verry's (1986) analysis indicated that peak flows immediately after snowmelt were significantly higher when the proportion of trees in a watershed $<15$ years old was $>50-60 \%$.

\section{In-stream monitoring: fish assemblages}

Fish were sampled using a single upstream pass with towed (larger streams) or backpack (smaller streams) electrofishing gear along a reach length of at least 35 mean stream widths as described for the habitat measurements. This distance typically encompasses three complete pool-riffle or two meander sequences (Leopold et al. 1964) and ensures that the cumulative number of species captured has reached or exceeded an asymptotic level for the stream segment (Lyons 1992b; Simonson and Lyons 1995). We used 300- to 500-V DC output pulsed at $60-120 \mathrm{~Hz}$ to produce no more than $2.5 \mathrm{~A}$ of current to minimize impacts on fish. Effort was made to thoroughly sample all habitats within a reach. Sampling was completed during July and early August when streams were at or near baseflow conditions and within a week or two of when habitat was sampled in a particular reach. All fish $>25 \mathrm{~mm}$ were identified, counted, and released except for those kept for identification verification. Fish identifications were based primarily on the taxonomic descriptions in Becker (1983).

We also classified all fish by a variety of autecological traits and guilds that we expected might respond to landscape and other environmental differences among our streams (see details in Brazner et al. (2002, 2004)). Swimming and shape factors were calculated as weighted averages per stream based on species quantitative factor values and abundances at each site. All other functional classifications were summarized as the proportion of fish within each class of a particular functional group at a given site. We used proportional rather than absolute abundances because we felt that the relative change in assemblage function in response to differences in environmental factors would be more ecologically informative and comparable across streams with different fish densities.

\section{Data analysis}

\section{Ordinations}

To assess responses of fish assemblages from western Lake Superior second- and third-order tributaries to regional, watershed, and in-stream environmental gradients and help determine which environmental factors were most important in driving these responses as part of meeting our first study objective, we employed nonmetric multidimensional scaling (NMDS) using PC-ORD software (McCune and Mefford 1997) to ordinate streams in species space. NMDS is an iterative ordination technique based on simple rank similarities among samples that linearizes the relationship between environmental- and species-based distances and effectively identifies responses to multiple environmental gradients (Faith et al. 1987; Clarke 1993).
We used Bray-Curtis dissimilarity as a distance measure to define our sample ranks. Species abundances were $\log (n+1)$ transformed. We checked for the presence of outliers using methods detailed in McCune and Mefford (1997). This involved comparing the average distance that a particular site is from all other sites with the average distance among all sites. Any site greater than two standard deviations away from the average distance would have been considered an outlier, but we found none. To increase the likelihood of finding optimal solutions to our ordinations, we obtained the starting axes to our NMDS runs from an initial Bray-Curtis ordination of the same data with variance-regression endpoint selection. Only three axes were calculated for each ordination because decreases in stress (a measure of correspondence between dissimilarity in the original space versus distance in the ordination space) were insignificant beyond that point (McCune and Mefford 1997). To evaluate the significance of axes obtained from NMDS runs, we ran Monte Carlo permutation tests (100 simulations) to assess the probability that sample scores in ordination space reflected a more accurate representation of compositional similarity than could be obtained using randomized versions of our data $(p \leq 0.01)$ (McCune and Mefford 1997).

Correlations between taxa abundance, functional group proportional abundance, environmental data, and NMDS axes were calculated to help assess which species and environmental variables may have had the strongest influence on differences among sites and how the functional composition of the assemblages varied among sites. Variables that were most highly correlated with the ordination axes were plotted as vector overlays originating from the centroid of the ordination plots. The angle and length of the vectors reflect the direction and strength of the relationship (McCune and Mefford 1997).

NMDS ordinations of streams in environmental space were also completed as another means of evaluating the influence of different environmental factors on differences among streams. Environmental data were relativized by adjusting to the standard deviate for each variable to account for large differences in scale among variable types. Correspondence among species- and environmental-based ordinations was evaluated using a Mantel test, which is a nonparametric test to evaluate the significance of the congruence (positive or negative association) between two dissimilarity matrices with a permutation method (Sokal and Rohlf 1995).

\section{ANCOVA}

After field reconnaissance and final site selection, refined GIS characterizations that included only the portions of watersheds above the reaches that were sampled (not completed until months after the field work was completed) indicated that the population of available watersheds in some cases occurred along gradients rather than easily discernable categories as indicated by initial watershed characterizations. Therefore, we used ANCOVA rather than conventional ANOVA to examine the significance of relationships between environmental variables that were highly correlated with streams in species space ordination axes $(r \geq 0.5)$ and landscape treatment variables. This was a more quantitative 
method for exploring linkages between landscape and finer scale environmental factors than provided by the ordinations. Identifying and quantifying these linkages was critical to meeting our second objective. We included watershed storage as a covariate in analyses for second-order streams and both watershed storage and percent mature forest as covariates in analyses for third-order streams. Region was evaluated as a main effect for both analyses. Although mature forest - fragmentation classes for second-order streams did not follow perfectly from our threshold selection criteria after GIS refinement (see Brazner et al. 2002), we felt that it was a close enough approximation to continue analyzing these data with mature forest as a categorical variable. One second-order site (Nemadji Creek) that was initially determined to be above the $50 \%$ mature forest threshold was actually found to be below it (40\% mature forest) after GIS refinement. However, we kept this site in the lowfragmentation class because it had the lowest level of recent logging (1.5\%) among all of our study sites (Brazner et al. 2002) and this maintained a balanced design for secondorder sites.

\section{Indicator species analysis (ISA)}

ISA (Dufrene and Legendre 1997) was used to estimate the significance of relationships between fish species and functional groups that were most strongly correlated $(r \geq$ $0.5)$ with the species-based ordination axes and the landscape treatment factors (hydrogeomorphic region, fragmentation, and watershed storage). The ISAs were needed to meet our third objective of identifying fish species and fish functional groups most indicative of particular conditions in the landscape. The statistical significance of an indicator value was evaluated against Monte Carlo results based on randomized site group assignments (McCune and Mefford 1997). Regional, fragmentation, and watershed storage indicators were calculated. This analysis required categorical assignment of sites to a particular group, so we assigned streams that had $\leq 50 \%$ mature forest to a high-fragmentation group and streams with $\geq 59 \%$ mature forest to a lowfragmentation group for both second- and third-order streams. Because of differences in the distributions of wetland and lake cover, our high- and low-storage categories varied between second- and third-order watersheds. For second-order streams, we assigned all streams with $\leq 10 \%$ watershed storage to a low-storage group and streams with $>20 \%$ storage to a high-storage group. For third-order streams, $<5 \%$ was classified as low storage and $>15 \%$ as high storage.

\section{Results}

\section{General environmental conditions}

Environmental conditions varied widely among streams (Appendix A) and are most easily summarized in an ordination context (Figs. 2 and 3); however, a few of the differences among sites are worth highlighting. Third-order sites were almost twice as wide but tended to be only slightly deeper and faster than second-order streams at baseflow. Although riparian buffer width was similar at second- and third-order sites, floodplain width was typically two times greater at third-order sites. In contrast, in-stream shade, sub-
Fig. 2. Ordination of second-order streams in species space using nonmetric multidimensional scaling of log fish abundances from sampling in 1997 during the comparative watershed study (proportion of distances among sites in the original data matrix accounted for by the first three axes in ordination space appear as an inset box in Fig. $2 a$; angle and length of vectors radiating from centroid of the ordination reflect the correlation $(r \geq 0.5)$ between ordination scores and environmental (italicized characters, broken lines) or fish species (bold characters, solid lines) abundances. Plot of $(a)$ axis 1 versus axis 2 and $(b)$ axis 1 versus axis 3.

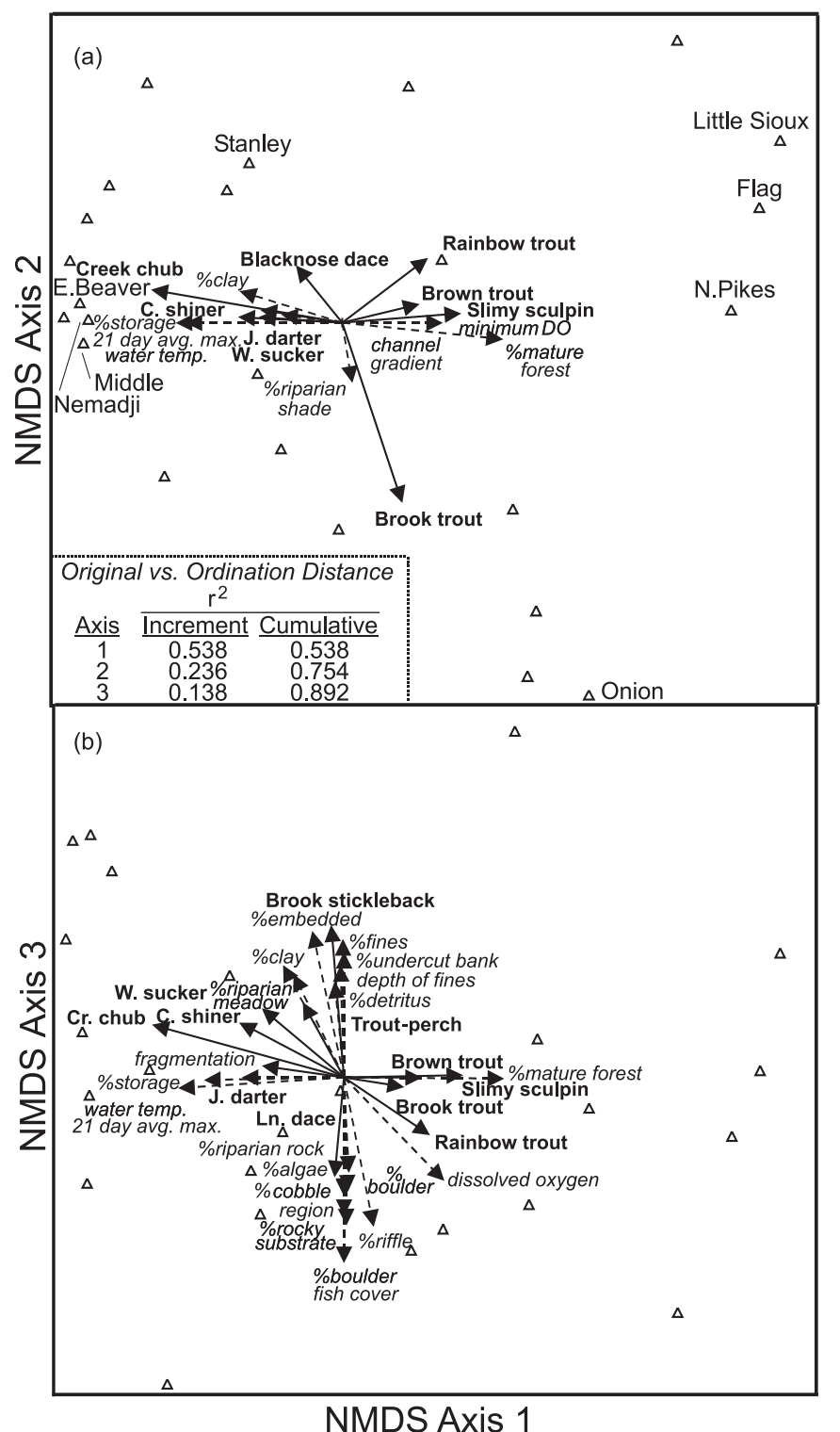

strate embeddedness, and average turbidity were all considerably higher at second-order sites. Among watershed variables, area, perimeter, and channel gradient were higher in all third-order watersheds, whereas storage was only higher in north shore watersheds. The streams in the Bayfield Sand Plains (Fig. 1) were distinguished by their low watershed storage, high percent mature forest, cold temperatures, and relatively large quantities of woody debris as fish cover. 
Fig. 3. Ordination of third-order streams in species space using nonmetric multidimensional scaling of log fish abundances from sampling in 1998 during the comparative watershed study (proportion of distances among sites in the original data matrix accounted for by the first three axes in ordination space appear as an inset box in Fig. $3 b$; angle and length of vectors radiating from centroid of the ordination reflect the correlation $(r \geq 0.5)$ between ordination scores and environmental (italicized characters, broken lines) or fish species (bold characters, solid lines) abundances. Plot of $(a)$ axis 1 versus axis 2 and $(b)$ axis 1 versus axis 3 .

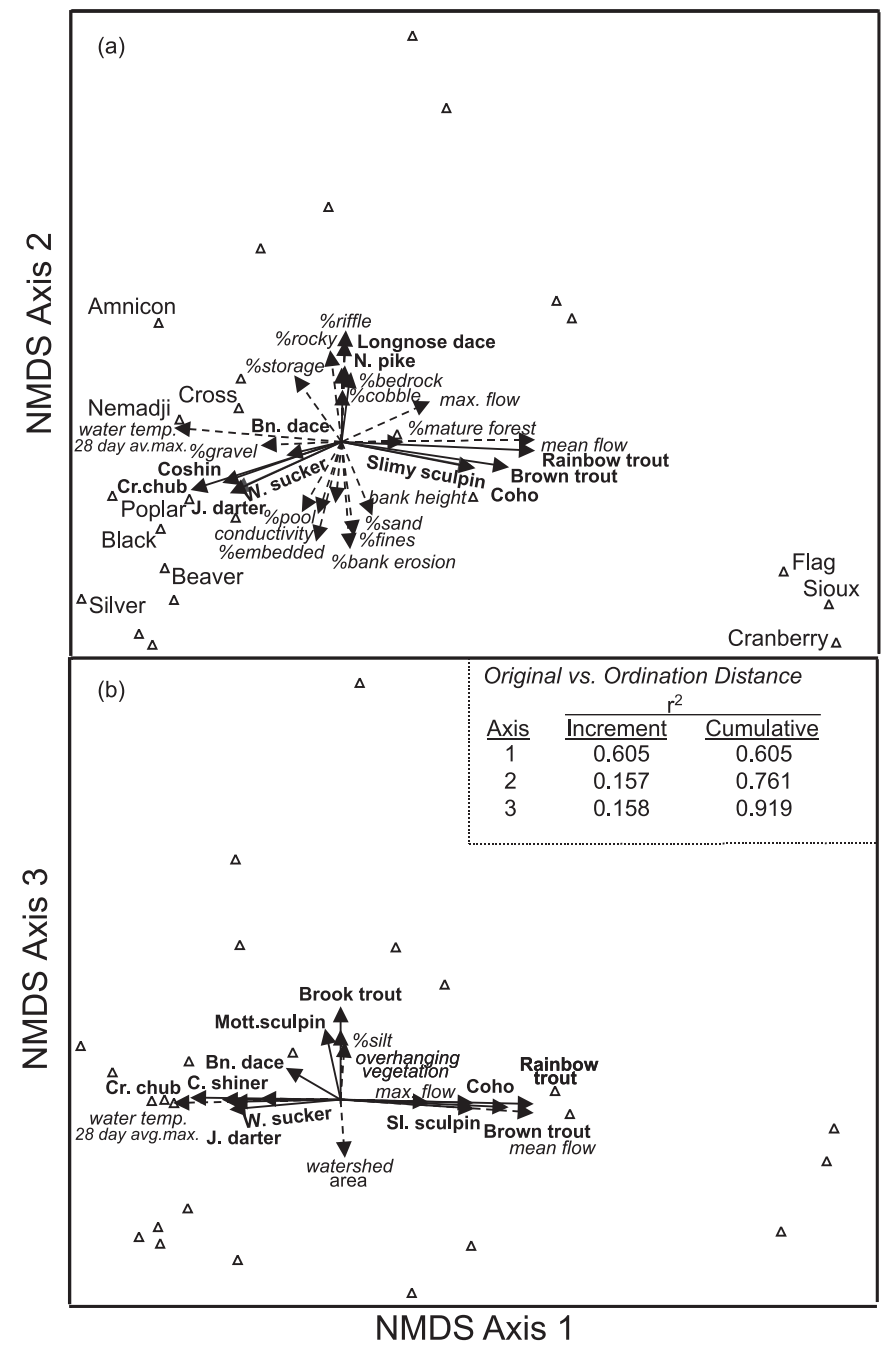

Streams on the north shore stand out for their high proportion of bedrock and rocky substrates, steep channel gradients, and somewhat higher maximum flows (Appendix A; Brazner et al. 2002).

\section{Fish demographics and assemblage patterns}

A total of 4290 individual fish comprising 28 species from 12 families were captured at second-order streams in 1997 and 14516 individuals comprising 37 species from 13 families were captured at third-order streams in 1998 (for additional details, see Brazner et al. 2002, 2004).

The NMDS solutions for the species-based ordinations on second- and third-order streams provided significantly greater reduction in ordination stress than expected by chance (Monte Carlo permutation tests, $p<0.01$ ), indicating that our three-dimensional solutions provide an accurate display of fish assemblage compositional dissimilarity among streams. The percentage of ecological distance among sites accounted for by the first three ordination axes was $89 \%$ for second-order streams (Fig. 2) and $92 \%$ for third-order streams (Fig. 3), indicating that these ordinations did an excellent job of recovering the ecological complexity of the original distance matrix. Axis 1 accounted for over $50 \%$ of the original distance among sites in both ordinations. The patterns apparent in the ordinations were quite similar for both second- and third-order sites. Environmental overlays demonstrate that percent mature forest - fragmentation level, percent watershed storage, water temperature, and flow were key factors associated with separation among our streams along axis 1 (Figs. 2 and 3). Second-order sites located along the upper half of axis 1 (e.g., North Pikes, Flag, Onion, and Little Sioux) were all among the highest in mature forest and coldest in water temperature, while second-order sites located along the lower part of axis 1 (e.g., Nemadji, East Beaver, Middle, and Stanley) typically had high watershed storage, high fragmentation, and warmer water (Fig. 2). Third-order sites along the upper part of axis 1 (Cranberry, Flag, and Sioux) were similar in character to second-order sites along this part of axis 1, except that separation among third-order sites appeared to be driven more by response to flow conditions (Fig. 3). These sites had higher mean and maximum flows compared with third-order sites on the lower part of axis 1 (e.g., Poplar, Black, Beaver, and Silver), which had warmer temperatures and high storage (e.g., Nemadji, Cross, and Amnicon). Salmonids and slimy sculpins (Cottus cognatus) were positively correlated with axis 1, while creek chubs (Semotilus atromaculatus), common shiners (Luxilus cornutus), johnny darters (Etheostoma nigrum), and white suckers (Catostomus commersoni) were most negatively correlated with it. Functionally, this translated into fishes that require cold water, have low silt tolerances and moderate current preferences, and tend to be large piscivores at sites along the upper portion of axis 1. Smallto medium-sized omnivorous, weaker swimming fishes with cool to warm temperature preferences, slow or general current preferences, and moderate to high silt tolerance characterized sites along the lower portion of axis 1 (Figs. 4 and $5)$. The strong correlation of percent mature forest and watershed storage with axis 1 , which accounted for the majority of variation explained in both ordinations, suggests that each of our watershed treatment factors has an important influence on fish assemblage patterns in the western Lake Superior region. However, since water temperature and flow were strong covariates with these treatment factors and also strongly correlated with axis 1 , it is difficult to determine their relative importance.

There was a strong regional signal in both ordinations as well. For second-order streams, it was along axis 3 and for third-order streams, it was along axis 2. South shore sites were characterized by brook sticklebacks (Culaea inconstans) and trout-perch (Percopsis omiscomaycus), while north shore streams were characterized by longnose dace (Rhinichthys cataractae) (Figs. $2 b$ and $3 a$ ) and to some extent rainbow trout (Oncorhynchus mykiss) (Fig. 2b) and northern pike 
Fig. 4. Ordination of second-order streams with proportional abundances of fish functional groups as overlay vectors. Angle and length of vectors radiating from centroid of the ordination reflect the correlation $(r \geq 0.5)$ between ordination scores and functional group abundances. Plot of $(a)$ axis 1 versus axis 2 and (b) axis 1 versus axis 3 .

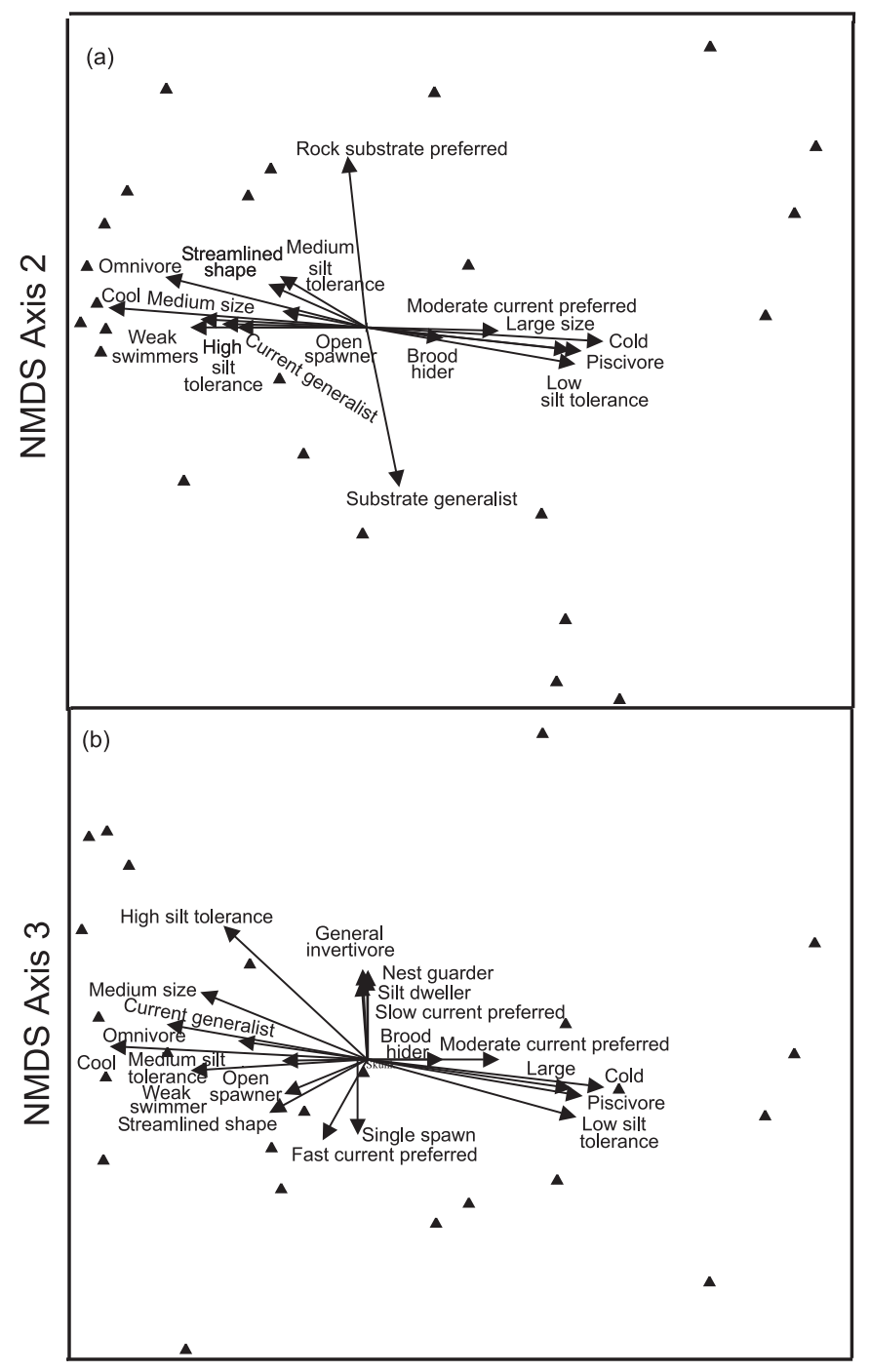

NMDS Axis 1

(Esox lucius) (Figs. 3b). Functionally, south shore fishes tended to be silt-dwelling, trophic generalists with slow current preferences and a tendency towards nest-guarding spawning behavior (Fig. 4b). North shore fishes tended to be single-bout spawners with fast current preferences (Figs. $4 b$ and $5 a$ ). Fine sediments, bank erosion, undercut banks, embedded substrates, and meadow in the riparian were typical habitat conditions associated with south shore sites, while north shore sites were typically rocky, dominated by riffle habitat, and had more prevalent periphyton communities (Figs. $2 b$ and $3 a$ ).

The remaining axis (axis 2, second order; axis 3, third order) in both ordinations was related to differences in brook trout (Salvelinus fontinalis). In second-order streams, brook trout streams were separated from other trout and warmwater streams by greater riparian shade, in contrast with streams
Fig. 5. Ordination of third-order streams with proportional abundances of fish functional groups as overlay vectors. Angle and length of vectors radiating from centroid of the ordination reflect the correlation $(r \geq 0.5)$ between ordination scores and functional group abundances. Plot of $(a)$ axis 1 versus axis 2 and $(b)$ axis 1 versus axis 3 .

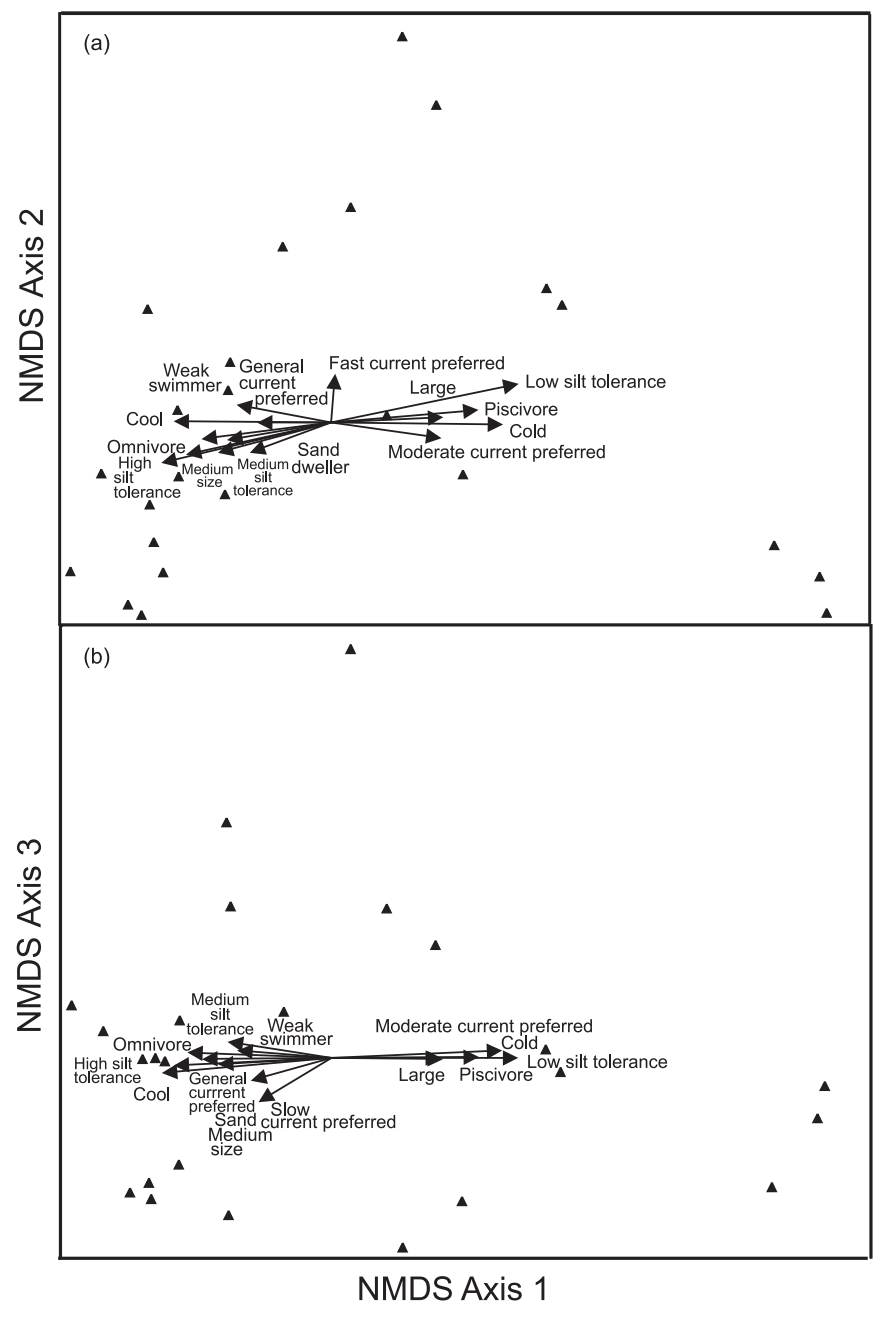

where blacknose dace (Rhinichthys atatulus) were most frequent, which were characterized by more open canopies and higher fragmentation (Fig. 2a). The only notable functional characters associated with fishes from these streams were that the brook trout streams were typified by substrate generalists and the dace streams were typified by rock-dwelling fishes. At third-order streams, brook trout occupied streams from smaller watersheds with extensive overhanging vegetation and silty substrates (Fig. 3b).

As one means of confirming that the environmental variables most strongly associated with the sites in species space ordinations were among the most important environmental factors in characterizing differences among our streams, we completed sites in environmental space ordinations (all environmental variables included). We compared the ecological distances among sites from these results with the distances among sites derived from the ordinations based on species abundances. We found a highly significant ( $p \leq 0.01)$ positive association between the environmental-based and the 
Table 1. ANCOVA results for habitat, water quality, riparian, and watershed variables from second-order streams that were highly correlated with sites in species space ordination axes.

\begin{tabular}{|c|c|c|c|c|c|c|c|}
\hline & \multirow[b]{2}{*}{$r$} & \multirow[b]{2}{*}{ Region (R) } & \multirow[b]{2}{*}{ Fragmentation $(\mathrm{F})$} & \multirow[b]{2}{*}{ Storage (ST) } & \multicolumn{3}{|c|}{ Interaction } \\
\hline & & & & & $\mathrm{R} \times \mathrm{F}$ & $\mathrm{F} \times \mathrm{ST}$ & $\mathrm{R} \times \mathrm{F} \times \mathrm{ST}$ \\
\hline \multicolumn{8}{|l|}{ In-stream habitat } \\
\hline Fish cover: boulders & 0.78 & $* * *$ & & & & & \\
\hline & & $\mathrm{N}>\mathrm{S}$ & & & & & \\
\hline Fish cover: undercut bank & 0.64 & $\begin{array}{l}* * * \\
\mathrm{~S}>\mathrm{N}\end{array}$ & & & & $* *$ & \\
\hline Rocky substrate (\%) & 0.70 & $\begin{array}{l}* * * \\
\mathrm{~N}>\mathrm{S}\end{array}$ & & & & & \\
\hline Riffle (\%) & 0.70 & $\begin{array}{l}* * * \\
\mathrm{~N}>\mathrm{S}\end{array}$ & & & & & \\
\hline Algae (\%) & 0.62 & $\begin{array}{l}* * * \\
\mathrm{~N}>\mathrm{S}\end{array}$ & & & & & \\
\hline Embeddedness $(\%)$ & 0.69 & $\begin{array}{l}* * * \\
\mathrm{~S}>\mathrm{N}\end{array}$ & & & & & \\
\hline Depth of fines & 0.61 & $\begin{array}{l}* * * \\
\mathrm{~S}>\mathrm{N}\end{array}$ & & & & & \\
\hline Physical-chemical & & & & & & & \\
\hline $\begin{array}{l}\text { Water temperature: } \\
\text { 21-day average maximum }\end{array}$ & 0.77 & & $\begin{array}{l}* * * \\
\mathrm{H}>\mathrm{L}\end{array}$ & $\begin{array}{l}* * * \\
\mathrm{H}>\mathrm{L}\end{array}$ & & $* *$ & \\
\hline Dissolved oxygen: minimum & 0.60 & & $\begin{array}{l}* * \\
\mathrm{~L}>\mathrm{H}\end{array}$ & & & & \\
\hline Riparian-watershed & & & & & & & \\
\hline Riparian meadow & 0.58 & $\begin{array}{l}* * \\
\mathrm{~S}>\mathrm{N}\end{array}$ & & & & & $* *$ \\
\hline Bank erosion & 0.54 & $* * *$ & $* *$ & $* * *$ & $* *$ & $* *$ & $* * *$ \\
\hline Channel gradient & 0.55 & $\mathrm{~S}>\mathrm{N}$ & $\mathrm{H}>\mathrm{L}$ & $\begin{array}{l}\mathrm{L}>\mathrm{H} \\
* * \\
\mathrm{~L}>\mathrm{H}\end{array}$ & & & \\
\hline
\end{tabular}

Note: $* * p<0.05, * * * p<0.01$; codes below $p$ values indicate the general direction of the relationship. $\mathrm{N}$, north shore; $\mathrm{S}$, south shore; $\mathrm{H}$, high; L, low; $r$, correlation with ordination axes. Storage was a covariate. $\mathrm{R} \times \mathrm{ST}$ interactions not shown because none was significant.

species-based distance matrices using Mantel's asymptotic approximation (Mantel 1967; Douglas and Endler 1982). This suggests that the main environmental drivers were similar for both ordination types and indicates that many of the same variables were important in structuring both the species-based and the environmental-based ordinations.

\section{Environmental patterns and landscape treatments}

Based on ANCOVA results, there were more significant regional differences in environmental variables than fragmentation or storage-related differences at both second- and third-order streams (Tables 1 and 2). The majority of environmental variables examined at second-order (9 of 12) and third-order (9 of 14) streams were significantly different between hydrogeomorphic regions. Percentage of rocky substrates, algal cover, and riffle area were greater at north shore sites, and percent embedded substrates, bank erosion, and percent fines - depth of fine substrates were all greater at south shore sites in both second- and third-order streams.

Variables that were most significantly different at sites with different mature forest - fragmentation levels included water temperature, conductivity, dissolved oxygen, and bank erosion, although responses were dependent on stream order. Water temperature was higher when fragmentation was high or mature forest was lower, but there was an important inter- action with storage. When fragmentation was low in secondorder streams, water temperature was positively related to storage. However, when fragmentation was high, water temperature was relatively high irrespective of storage level, suggesting that fragmentation had an overriding influence. In third-order watersheds, the influence of forest cover on water temperature varied by region. Along the south shore, streams with more mature forest had lower water temperatures, but this trend was much weaker along the north shore. Conductivity was higher at third-order sites when mature forest was lower (Table 2), dissolved oxygen had higher minimums at low-fragmentation second-order sites (Table 1), and bank erosion was higher when fragmentation was higher in second-order streams. Interactions indicate that bank erosion was less important at second-order sites on the north shore (Table 1). This is not surprising, since north shore sites are typically dominated by rock and much less susceptible to erosive forces.

Variables that were most significantly different at sites with different storage levels were water temperature, bank erosion, conductivity, dissolved oxygen, watershed area, and channel gradient (Tables 1 and 2). Water temperature was higher when storage was higher at both second- and thirdorder sites. Bank erosion was much higher along secondorder streams when storage was low, but interactions suggest 
Table 2. ANCOVA results for habitat, water quality, riparian, and watershed variables from third-order streams that were highly correlated with sites in species space ordination axes.

\begin{tabular}{|c|c|c|c|c|c|c|}
\hline & \multirow[b]{2}{*}{$r$} & \multirow[b]{2}{*}{ Region (R) } & \multirow[b]{2}{*}{$\begin{array}{l}\text { Mature } \\
\text { forest }(\mathrm{MF})\end{array}$} & \multirow[b]{2}{*}{$\begin{array}{l}\text { Storage } \\
(\mathrm{ST})\end{array}$} & \multicolumn{2}{|c|}{ Interaction } \\
\hline & & & & & $\mathrm{R} \times \mathrm{ST}$ & $\mathrm{R} \times \mathrm{MF}$ \\
\hline \multicolumn{7}{|l|}{ In-stream habitat } \\
\hline Riffle $(\%)$ & 0.74 & $* *$ & & & & \\
\hline Embeddedness $(\%)$ & 0.71 & $\begin{array}{l}\mathrm{N}>\mathrm{S} \\
* * *\end{array}$ & & & & \\
\hline Fine substrates $(\%)$ & 0.68 & $\begin{array}{l}\mathrm{S}>\mathrm{N} \\
* * *\end{array}$ & & & & \\
\hline & & $\mathrm{S}>\mathrm{N}$ & & & & \\
\hline Rocky substrates (\%) & 0.67 & $\begin{array}{l}* * * \\
\mathrm{~N}>\mathrm{S}\end{array}$ & & & & \\
\hline Gravel (\%) & 0.56 & & L* $>\mathrm{H}$ & & & \\
\hline Algae $(\%)$ & 0.51 & $\begin{array}{l}* * * \\
\mathrm{~N}>\mathrm{S}\end{array}$ & & & & \\
\hline Physical-chemical & & & & & & \\
\hline Mean flow: baseflow & 0.86 & $\begin{array}{l}* * \\
\mathrm{~N}>\mathrm{S}\end{array}$ & & & & \\
\hline $\begin{array}{l}\text { Water temperature: } \\
28 \text {-day average maximum }\end{array}$ & 0.80 & & L* $>\mathrm{H}$ & $\begin{array}{l}* * * \\
\mathrm{H}>\mathrm{L}\end{array}$ & & $* *$ \\
\hline Flow: maximum & 0.58 & $\begin{array}{l}* * \\
\mathrm{~N}>\mathrm{S}\end{array}$ & & & & $* *$ \\
\hline Conductivity & 0.58 & & $\begin{array}{l}* * * \\
\mathrm{~L}>\mathrm{H}\end{array}$ & $\begin{array}{l}* * * \\
\mathrm{~L}>\mathrm{H}\end{array}$ & $* *$ & \\
\hline Dissolved oxygen: maximum & 0.50 & & & $\begin{array}{l}* * \\
\mathrm{H}>\mathrm{L}\end{array}$ & & \\
\hline Riparian-watershed & & & & & & \\
\hline Bank erosion & 0.73 & $\begin{array}{l}* * * \\
\mathrm{~S}>\mathrm{N}\end{array}$ & & & & $* *$ \\
\hline Watershed area & 0.55 & & & $\begin{array}{l}* * \\
\mathrm{H}>\mathrm{L}\end{array}$ & & \\
\hline Bank height & 0.55 & $\begin{array}{l}* * * \\
\mathrm{~S}>\mathrm{N}\end{array}$ & & & & \\
\hline
\end{tabular}

Note: $* * p<0.05, * * * p<0.01$; codes below $p$ values indicate the general direction of the relationship. $\mathrm{N}$, north shore; $\mathrm{S}$, south shore; $\mathrm{H}$, high; L, low; $r$, correlation with ordination axes. Mature forest and storage were covariates; therefore, no three-way interations were tested.

that this was less important when fragmentation was low as well. Conductivity was lower at third-order sites when storage was low (Table 2), dissolved oxygen had higher maximums and watershed area was larger for third-order streams from high-storage watersheds (Table 2), and channel gradient was higher in second-order streams from low-storage watersheds (Table 1). So, it is clear that many of the environmental variables that were most closely associated with the ordination results were also significantly associated with landscape treatment variables. However, in some cases, the effects were dependent on interactions among the landscape variables (e.g., relationship of fish cover to mature forest and storage conditions).

\section{ISA}

Results from the ISAs were useful in developing biological indicators of watershed condition. It was reassuring that several of the species (brook stickleback, trout-perch, and longnose dace) that were most strongly correlated with the regional axes in the ordinations were among the best regional indicators in our ISAs (Table 3). Similarly, the best fragmentation and storage indicators were also species that were highly correlated with the ordination axes associated with storage and fragmentation; brook trout and slimy sculpins reflected the least degraded forest conditions, and common shiners and mottled scuplins (Cottus bairdi) best typified high-storage watersheds.

The ordination results were also validated by indicator analysis from a functional perspective. Most of the same fish functional groups that were highly correlated with the fragmentation - mature forest, region, and storage-associated ordination axes were also the best indicators of these watershed characters in the ISAs. The low-fragmentation indicators (low silt tolerance, cold water preference, large, piscivorous, moderate current preference) and high-fragmentation indicators (medium sized, omnivorous, cool water preference, high silt tolerance) (Table 4) from the ISAs were virtually identical to the functional groups highlighted in the ordination 
Table 3. Results of indicator species analysis (ISA) used to examine significance $(p<0.05)$ of relationships between fish species and landscape factors.

\begin{tabular}{|c|c|c|c|c|}
\hline & \multicolumn{2}{|l|}{ Second-order streams, 1997} & \multicolumn{2}{|l|}{ Third-order streams, 1998} \\
\hline & Indicator species & $p$ & Indicator species & $p$ \\
\hline \multicolumn{5}{|c|}{ Region } \\
\hline \multirow[t]{3}{*}{ South } & Brook stickleback (Culaea inconstans) & 0.004 & Trout-perch (Percopsis omiscomaycus) & 0.021 \\
\hline & Slimy sculpin (Cottus cognatus) & 0.039 & Johnny darter (Etheostoma nigrum) & 0.028 \\
\hline & Central mudminnow (Umbra limi) & 0.054 & & \\
\hline \multirow[t]{2}{*}{ North } & ns & & Longnose dace (Rhinichthys cataractae) & 0.010 \\
\hline & & & Brook trout (Salvelinus fontinalis) & 0.023 \\
\hline \multicolumn{5}{|c|}{ Fragmentation } \\
\hline Low & Brook trout & 0.042 & Slimy sculpin & 0.019 \\
\hline \multirow[t]{5}{*}{ High } & Creek chub (Semotilus atromaculatus) & 0.016 & Creek chub & 0.001 \\
\hline & Johnny darter & 0.027 & Johnny darter & 0.003 \\
\hline & Blacknose dace (Rhinichthys atatulus) & 0.043 & White sucker (Catostomus commersoni) & 0.003 \\
\hline & & & Common shiner (Luxilus cornutus) & 0.003 \\
\hline & & & Fathead minnow (Pimephales promelas) & 0.039 \\
\hline \multicolumn{5}{|c|}{ 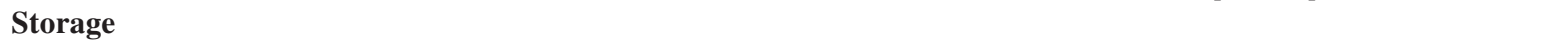 } \\
\hline \multirow[t]{3}{*}{ Low } & Slimy sculpin & 0.005 & Brown trout (Salmo trutta) & 0.005 \\
\hline & & & Slimy sculpin & 0.006 \\
\hline & & & Coho salmon (Oncorhychus kisutch) & 0.017 \\
\hline \multirow[t]{3}{*}{ High } & Common shiner & 0.007 & Mottled sculpin (Cottus bairdi) & 0.029 \\
\hline & Mottled sculpin & 0.016 & & \\
\hline & White sucker & 0.044 & & \\
\hline
\end{tabular}

Note: See text for definitions of storage and fragmentation classes; ns, no significant species.

Table 4. Results of indicator group analysis used to examine significance $(p<0.05)$ of relationships between fish functional groups and landscape factors.

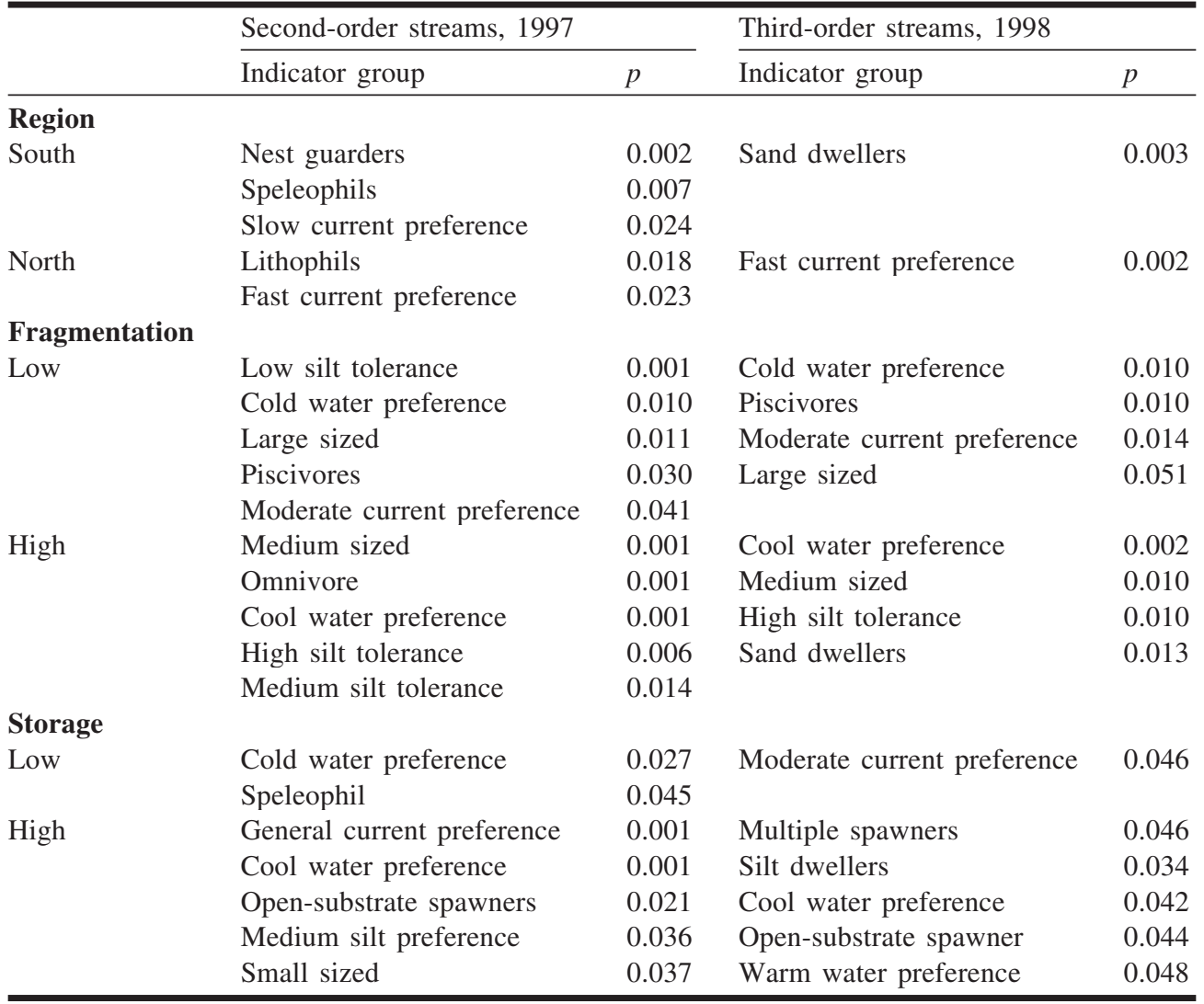

Note: See text for definitions of storage and fragmentation classes. 
plots (Figs. 4 and 5). The function-based storage indicators, although similar to groups identified in the ordinations, also identified spelelophils and multiple spawners as good indicators of different storage conditions.

\section{Discussion}

Despite all of the complexities involved in conducting a comparative watershed study at the regional scale, we were still able to elucidate a number of important relationships among landscape, habitat, and fish assemblage characters that allowed us to successfully meet most of our objectives. We certainly gained a better understanding of the interrelationships among various landscape and in-stream habitat variables (our second objective), and we were also able to identify species and functional characters of the fish assemblages that were most indicative of particular landscape conditions (our third objective). It was difficult to quantify the relative importance of any one particular scale of process (e.g., local, watershed, regional) because of the strong interdependencies that typically exist among them (e.g., Richards et al. 1996), although the strength of this interdependency can vary from region to region (e.g., Minshall et al. 1983). So, we were not able to fully meet the goal of our first objective which was to determine the relative influence of different environmental factors at multiple spatial scales. However, our results do provide support for a number of the landscape-habitat-biota linkages that we hypothesized and some strong indications about which environmental factors were most important in driving the patterns in fish assemblages that we observed: high watershed storage was associated with higher water temperatures and minnowsucker-darter assemblages with higher silt tolerances, warmer temperature and general or slow current preferences, and low storage was associated with low fragmentation, cold water temperatures, and salmonid-sculpin assemblages with low silt tolerance, cold water and moderate current preferences, and piscivorous feeding tendencies. We believe that the low storage - low fragmentation association along the south shore was merely a coincidence of the geology of the watersheds that we studied rather than a general landscape pattern that should be expected in other regions (e.g., there is no reason to believe that low fragmentation precludes high storage or vice versa), but the low fragmentation association with colder water and salmonid assemblages is likely a common landscape-biota connection (Steedman 1988; Maret et al. 1997). It appears that watersheds comprised of a high proportion of mature forest have cooler water temperatures and possibly increased ground water influence (Barton et al. 1985), whereas high watershed storage results in higher stream water temperatures by acting as a direct source of warmer water and by moderating flow and increasing water residence time within the stream (Jacques and Lorenz 1988; Krug et al. 1992). The differences in geology between north and south shore watersheds (particularly those in the Bayfield Sand Plains; Maxwell et al. 1995) could have an important influence on the responses of streams to further change in forest cover. Greater groundwater inputs from the sand moraines along the south shore relative to the more bedrock-laden north shore (Albert 1995) suggests that north shore streams will be more susceptible to water temperature rises following additional forest cutting, since groundwater sources are less likely to moderate the effects of decreased shading.

The fact that more environmental variables differed significantly among regions than at sites with different fragmentation or storage levels suggests that underlying geology and soils, and other regionally varying factors (e.g., gradient), probably had the most important role in structuring habitat in and adjacent to our study streams. Although the greatest number of environmental variables differed significantly across hydrogeomorphic regions, there were surprisingly few strong individual species or fish functional group associations with these axes in the ordinations. This indicates that the potential for regionally driven differences in the assemblages, although large, was not fully realized and suggests that our other landscape treatments may have had more important influences on fish assemblage structure and function. These effects were manifest through effects on water temperature, bank erosion, dissolved oxygen, fish cover, and a number of other factors. It appeared that in some circumstances, forest cover had a stronger role in controlling environmental conditions and influencing fish assemblages at a site than watershed storage because when fragmentation was low, the influence of storage on variables such as bank erosion or the occurrence of undercut banks as fish cover was weak or undetectable. So, the relative influence among the landscape treatment variables is dependent on both their interaction with each other and the habitat or fish assemblage character of interest. Developing more predictive models that relate in-stream habitat, water quality, and riparian conditions to landscape factors will be critical for improving our ability to make accurate predictions about the likely effects of land-use change on in-stream biotic conditions. The ordination and ANCOVA results presented here are a first step in this direction.

Our results are interesting in light of other studies that have tried to identify the relative importance of local and regional processes in structuring biotic assemblages. Although there have been relatively few efforts specifically focused on the relative effects of both local and regional processes on the structure and function of biotic assemblages in streams, there seems to be a difference in the balance of control for different assemblage types. Macroinvertebrate and phytobenthos assemblages seem to be more under the proximate control of local factors such as in-stream habitat and substrate (e.g., Richards et al. 1997; Sponseller et al. 2001), whereas fish assemblage patterns seem to be more strongly influenced by watershed and landscape factors (Mensing et al. 1998; Sharma and Hilborn 2001). However, studies have also shown that geology and land use strongly influence in-stream habitat known to be important to fish (Richards et al. 1996; Johnson et al. 1998), again begging the question of proximate versus ultimate cause. In lakes, where more effort has been made to answer this question, a balance of local and regional processes has been found to control both macroinvertebrate and fish assemblages (Tonn et al. 1990; Allen et al. 1999), although Kelso and Minns (1996) concluded that regional influences primarily structured fish assemblages in the Canadian Great Lakes. Wang et al. (2003) concluded that watershed character plays an increasingly important role as human development in the landscape increases. Determining 
the relative influence of landscape and habitat features seems likely to remain a difficult problem because their influences may be inextricably linked in most situations. The biggest challenge may be in finding the landscape measure(s) that best characterizes this linkage, since it seems likely to vary from place to place. We think this issue deserves considerably more attention in future studies of lake and stream biota that use a landscape approach.

We also think that additional effort should be made to understand the response of fish assemblages to logging rather than just the responses of particular populations or groups of fishes. The focus has been almost exclusively oriented toward effects on salmonid populations (Meehan 1991; Spence et al. 1996) or salmonid diversity (Reeves et al. 1993). Although logging has not been a focus, a more landscape-oriented perspective has been adopted by some assemblage-oriented fish ecologists studying effects of various other anthropogenic disturbances (e.g.,Walser and Bart 1999; Schleiger 2000). Many of the current approaches to estimating biotic integrity have included quantification of forest cover and other land uses as integral parts of their studies (e.g., Maret et al. 1997; Wang et al. 2003).

Our results have implications for index of biotic integrity development in this region. They suggest that a finer-scale approach may be important. Ordinations detected considerable variation in fish assemblages across this region, even though our study watersheds were all within one ecoregion (Northern Lakes and Forests; Omernik and Gallant 1988). Since overall differences in fish assemblages were closely associated with the finer-scaled ecological units containing our watersheds, it may be that the classification systems suggested by Maxwell et al. (1995) and Albert (1995) should receive increased attention by resource managers in future efforts to develop indices of biotic integrity or other biocriteria. The results of our ISAs should provide a reasonable set of metrics for initial testing of these sorts of biocriteria.

From a management perspective, our results suggest that both timber management and wetland restoration or degradation decisions will need to be considered by resource managers when fish community health is a concern. For example, increasing percentages of mature forest cover should allow for salmonid-sculpin assemblages to become more prevalent in streams with the potential for cool or cold waters. Similarly, increased wetland cover should allow for a greater predominance of healthy warmwater fish assemblages assuming that other landscape features are not too badly degraded. By understanding the species structure and functional character of an assemblage and its relationship to landscape features, managers should be able to make at least a rough assessment of watershed condition. Lacking fish data, it might be easier to simply characterize forest cover and storage as a first step in identifying which watersheds likely contain streams that are degraded. Our results suggest that although in-stream habitat rehabilitation should continue to be used an important tool to improve biological conditions in streams, restoration efforts will have greater success if the potential interactions with landscape conditions are factored into the decision-making process. In some situations, manipulation of forest cover or watershed storage may have a greater impact on fish assemblage integrity than in-stream habitat improvements.

\section{Acknowledgments}

We thank all of the members of the Watershed Diagnostics Research Team at the Mid-Continent Ecology Division in Duluth for a wide variety of help in completing the field portions of this project. Karen Olsen's help in the field and in the laboratory for data entry was invaluable. Shawn Fabbro, Ryan Blazevik, Terry Jicha, and John Morrice were especially helpful in the field. Robert DuBois, John Lindgren, and Steve Schram provided valuable input about local stream ecology, and Joel Ebersole, Jo Thompson, and two anonymous reviewers provided insightful comments that improved this manuscript. The information in this document has been funded wholly by the US Environmental Protection Agency. It has been subjected to review by the National Health and Environmental Effects Research Laboratory and approved for publication. Approval does not signify that the contents reflect the views of the Agency, nor does mention of trade names or commercial products constitute endorsement or recommendation for use.

\section{References}

Albert, D.A. 1995. Regional landscape ecosystems of Michigan, Minnesota, and Wisconsin: a working map and classification (fourth revision: July 1995). US For. Serv. Gen. Tech. Rep. NC-178.

Allen, A.P., Whittier, T.R., Larsen, D.P., Kaufman, P.R., O'Connor, R.J., Hughes, R.M., Stemberger, R.S., Dixit, S.S., Brinkhurst, R.O., Herlihy, A.T., and Paulsen, S.G. 1999. Concordance of taxonomic composition patterns across multiple lake assemblages: effects of scale, body size, and land use. Can. J. Fish. Aquat. Sci. 56: 2029-2040.

Angermeier, P.L., and Schlosser, I.J. 1989. Species-area relationships for stream fishes. Ecology, 70: 1450-1462.

Angermeier, P.L., and Winston, M.R. 1999. Characterizing fish community diversity across Virginia landscapes: prerequisite for conservation. Ecol. Appl. 9: 335-349.

Barton, D.R., Taylor, W.D., and Biette, R.M. 1985. Dimensions of riparian buffer strips required to maintain trout habitat in southern Ontario streams. N. Am. J. Fish. Manag. 5: 364-378.

Becker, G.C. 1983. Fishes of Wisconsin. University of Wisconsin Press, Madison, Wis.

Bisson, P.A., and Sedell, J.R. 1984. Salmonid populations in streams in clearcut vs. old-growth forests of western Washington. In Proceedings: Fish and Wildlife Relationships in Oldgrowth Forest Symposium. Edited by W.R. Meehan, M.A. Brusven, and J.F. Ward. American Institute of Fishery Research Biologists, Asheville, N.C. pp. 121-129.

Brazner, J.C., Tanner, D.K., Detenbeck, N.E., Batterman, S.L., Stark, S.L., Jagger, L.A., and Snarski, V.M. 2002. Does forest fragmentation, watershed storage, or regional hydrogeomorphology structure fish assemblages in western Lake Superior streams? Internal Report, US Environmental Protection Agency, National Health and Environmental Effects Research Laboratory, MidContinent Ecology Division, Duluth, Minn.

Brazner, J.C., Tanner, D.K., Detenbeck, N.E., Batterman, S.L., Stark, S.L., Jagger, L.A., and Snarski, V.M. 2004. Landscape character and fish assemblage structure and function in western Lake Superior streams: general relationships and identification of thresholds. Environ. Manag. 33: 855-875.

Clarke, K.R. 1993. Non-parametric multivaritate analyses of changes in community structure. Aust. J. Ecol. 18: 117-143. 
Detenbeck, N.E., Johnston, C.A., and Niemi, G.J. 1993. Wetland effects on lake water quality in the Minneapolis/St. Paul metropolitan area. Landscape Ecol. 8: 39-61.

Detenbeck, N.E., Batterman, S.L., Brady, V.J., Brazner, J.C., Snarski, V.M., Taylor, D.L., Thompson, J.A., and Arthur, J.W. 1997. Research plan for Lake Superior comparitive watershed study. US Environmental Protection Agency, Mid-Continent Ecology Division, Duluth, Minn.

Detenbeck, N.E., Batterman, S.L., Brady, V.J., Brazner, J.C., Snarski, V.M., Taylor, D.L., Thompson, J.A., and Arthur, J.W. 2000. The western Lake Superior watershed framework: a test of geographically-dependent vs. geographically-independent, threshold-based watershed classification systems for ecological risk assessment. Environ. Toxicol. Chem. 19: 1174-1181.

Douglas, M.E., and Endler, J.A. 1982. Quantitative matrix comparisons in ecological and evolutionary investigations. J. Theor. Biol. 99: 777-795.

Dufrene, M., and Legendre, P. 1997. Species assemblages and indicator species: the need for a flexible asymmetrical approach. Ecol. Monogr. 67: 345-366.

Faith, D.P., Minchin, P.R., and Belbin, L. 1987. Compositional dissimilarity as a robust measure of ecological distance. Vegetatio, 69: $57-68$.

Gorman, O.T., and Karr, J.R. 1978. Habitat structure and stream fish communities. Ecology, 59: 507-515.

Government of Canada and US Environmental Protection Agency. 1995. The Great Lakes atlas: an environmental atlas and resource book. Government of Canada, Toronto, Ont., and US Environmental Protection Agency, Great Lakes National Program Office, Chicago, Ill.

Hartman, G.F., Scrivener, J.C., and Miles, M.J. 1996. Impacts of logging in Carnation Creek, a high-energy coastal stream in British Columbia, and their implication for restoring fish habitat. Can. J. Fish. Aquat. Sci. 53: 237-251.

Hey, D.L., and Wickenkamp, J.A. 1996. Some hydrologic effects of wetlands in nine watersheds of southeastern Wisconsin. Great Lakes Wetlands, 7: 4-9.

Hughes, R.M., Rexstad, E., and Bond, C.E. 1987. The relationship of aquatic ecoregions, river basins and physiographic provinces to the ichthyogeographic regions of Oregon. Copeia, 2: 423-432.

Jacques, J.E., and Lorenz, D.L. 1988. Techniques for estimating the magnitude and frequency of floods of ungauged streams in Minnesota. Water Resour. Invest. Rep. 87-4170. US Geological Survey, Washington, D.C.

Johnson, L.B., Host, G.E., and Richards, C. 1998. Hierarchical influences of channel, riparian, and landscape features on coarse woody debris in low-gradient, midwestern streams. Natural Resource Research Institute, Duluth, Minn. Tech. Rep. NRRI/TR-98/24.

Johnston, C.A. 1990. Land-use activities and western Lake Superior water quality. In Making a Great Lake Superior: Proceedings from the 1990 International Conference on Remedial Action Plans in the Lake Superior Basin. Edited by J. Vander Wal and P.D. Watts. Lakehead University, Thunder Bay, Ontario. pp. 145-162.

Johnston, C.A., Detenbeck, N.E., and Niemi, G.J. 1990. The cumulative effect of wetlands on stream water quality and quantity: a landscape approach. Biogeochemistry, 10: 105-141.

Keddy, P.A. 1992. A pragmatic approach to functional ecology. Funct. Ecol. 6: 621-626.

Kelso, R.M., and Minns, C.K. 1996. Is fish species richness at sites in the Canadian Great Lakes the result of local or regional factors? Can. J. Fish. Aquat. Sci. 53: 175-193.

Keys, J.E., Jr., Carpenter, C.A., Hooks, S.L., Kownig, F.G., McNab, W.H., Russell, R.E., and Smith, M.L. 1995. Ecological units of the eastern United States: first approximation (map and booklet of map tables). US Department of Agriculture, Forest Service, Atlanta, Ga.

Krug, W.R., Conger, D.H., and Gebert, W.A. 1992. Floodfrequency characteristics of Wisconsin streams. US Geological Survey, Madison, Wis. Water Resour. Invest. Rep. 91-4128.

Leopold, L.B., Wolman, W.G., and Miller, J.P. 1964. Fluvial processes in geomorphology. Freeman Company, St. Louis, Mo.

Lyons, J. 1992a. The length of stream to sample with a towed electrofishing unit when fish species richness is estimated. N. Am. J. Fish. Manag. 12: 198-203.

Lyons, J. 1992b. Using the index of biotic integrity (IBI) to measure environmental quality in warmwater streams of Wisconsin. US For. Serv. Gen. Tech. Rep. NC-149.

Mantel, N. 1967. The detection of disease clustering and generalized regression approach. Cancer Res. 27: 209-220.

Maret, T.R., Robinson, C.T., and Minshall, G.W. 1997. Fish assemblages and environmental correlates in least-disturbed streams of the upper Snake River basin. Trans. Am. Fish. Soc. 126: 200216.

Maxwell, J.R., Edwards, C.J., Jensen, M.E., Paustian, S.J., Parrott, H., and Hill, D.M. 1995. A hierarchical framework of aquatic ecological units in North America (Nearctic Zone). US For. Serv. Gen. Tech. Rep. NC-176.

McCune, B., and Mefford, M.J. 1997. PC-ORD: multivaritate analysis of ecological data. MJM Software Design, Gleneden Beach, Oreg.

Meador, M.R., Cuffney, T.F., and Gurtz, M.E. 1993a. Methods for sampling fish communities as part of the national water-quality assessment program. US Geol. Surv. Open-File Rep. 93-104.

Meador, M.R., Hupp, C.R., Cuffney, T.F., Gurtz, M.E. $1993 b$. Methods for characterizing stream habitat as part of the national water-quality assessment program. US Geol. Surv. Open-File Rep. 93-408.

Meehan, W.R. (Editor). 1991. Influences of forest and rangeland management on salmonid fishes and their habitats. Am. Fish. Soc. Spec. Publ. 19.

Mensing, D.M., Galatowitsch, S.M., and Tester, J.R. 1998. Anthropogenic effects on the biodiversity of riparian wetlands of a northern temperate landscape. J. Environ. Manag. 53: 349-377.

Minshall, G.W., Petersen, R.C., Cummins, K.W., Bott, T.L., Sedell, J.R., Cushing, C.E., and Vannote, R.L. 1983. Interbiome comparisons of stream ecosystem dynamics. Ecol. Monogr. 53: 1-25.

Murphy, M.L. 1995. Forestry impacts on freshwater habitat of anadromous salmonids in the Pacific Northwest and Alaska - requirements for protection and restoration. NOAA Coastal Ocean Office, Silver Spring, Md. NOAA Coast. Ocean Prog. Dec. Anal. Ser. No. 7.

Omernik, J.M., and Gallant, A.L. 1988. Ecoregions of the upper Midwest states. US Environmental Protection Agency, Environmental Research Laboratory, Corvallis, Oreg. Rep. EPA/600/3-88/037.

Platts, W.S., Megehan, W.F., and Minshall, G.W. 1983. Methods for evaluating stream, riparian, and biotic conditions. US For. Serv. Gen. Tech. Rep. INT-138.

Poff, N.L. 1997. Landscape filters and species traits: towards mechanistic understanding and prediction in stream ecology. J. North Am. Benthol. Soc. 16: 391-409.

Poff, N.L., and Allan, J.D. 1995. Functional organization of stream fish assemblages in relation to hydrologic variability. Ecology, 76: 606-627.

Reeves, G.H., Everest, F.H., and Sedell, J.R. 1993. Diversity of anadromous salmonid assemblages in coastal Oregon basins with different levels of timber harvest. Trans. Am. Fish. Soc. 122: 309-317. 
Richards, C., Johnson, L.B., and Host, G.E. 1996. Landscape-scale influences on stream habitats and biota. Can. J. Fish. Aquat. Sci. 53: $295-311$.

Richards, C., Haro, R.J., Johnson, L.B., and Host, G.E. 1997. Catchment and reach scale properties as indicators of macroinvertebrate species traits. Freshw. Biol. 37: 219-230.

Schleiger, S.L. 2000. Use of an index of biotic integrity to detect effects of land uses on stream fish communities in west-central Georgia. Trans. Am. Fish Soc. 129: 1118-1133.

Schlosser, I.J. 1982. Fish community structure and function along two habitat gradients in a headwater stream. Ecol. Monogr. 52: 395-414.

Schlosser, I.J. 1990. Environmental variation, life history attributes, and community structure in stream fishes: implications for environmental management and assessment. Environ. Manag. 14: $621-628$.

Sharma, R., and Hilborn, R. 2001. Empirical relationships between watershed characteristics and coho salmon (Oncorhychus kisutch) smolt abundance in 14 western Washington streams. Can. J. Fish. Aquat. Sci. 58: 1453-1463.

Simonson, T.D., and Lyons, J. 1995. Comparison of catch per unit effort and removal procedures for sampling stream fish assemblages. N. Am. J. Fish. Manag. 15: 419-427.

Simonson, T.D., Lyons, J., and Kanehl, P.D. 1994a. Quantifying fish habitat in streams: transect spacing, sample size, and a proposed framework. N. Am. J. Fish. Manag. 14: 607-615.

Simonson, T.D., Lyons, J., and Kanehl, P.D. 1994b. Guidelines for evaluating fish habitat in Wisconsin Streams. US For. Serv. Gen. Tech. Rep. NC-164.

Sokal, R.R., and Rohlf, F.J. 1995. Biometry. W.H. Freeman, San Francisco, Calif.

Spence, B.C., Lomnicky, G.A., Hughes, R.M., and Novitzki, R.P. 1996. An ecosystem approach to salmonid conservation. ManTech Environmental Research Services Corp., Corvallis, Oreg. Tech. Rep. TR-4501-96-6057.
Sponseller, R.A., Benfield, E.F., and Valett, H.M. 2001. Relationships between land-use, spatial scale and stream macroinvertebrate communities. Freshw. Biol. 46: 1409-1424.

Steedman, R.J. 1988. Modification and assessment of an index of biotic integrity to quantify stream quality in southern Ontario. Can. J. Fish. Aquat. Sci. 45: 492-501.

Tonn, W.M., Magnuson, J.J., Rask, M., and Toivonen, J. 1990. Intercontinental comparison of small-lake fish assemblages: the balance between local and regional processes. Am. Nat. 136: 345-375.

Verry, E.S. 1986. Forest harvesting and water: the Lake States experience. Water Resour. Bull. 22: 1039-1047.

Walser, C.A., and Bart, H.L., Jr. 1999. Influence of agriculture on instream habitat and fish community structure in Piedmont watersheds of the Chattahoochee River system. Ecol. Freshw. Fish, 8: 237-246.

Wang, L., Lyons, J., Kanehl, P., and Gatti, R. 1997. Influences of watershed land use on habitat quality and biotic integrity in Wisconsin streams. Fisheries, 22: 6-12.

Wang, L., Lyons, J., Rasmussen, P., Seelbach, P., Simon, T., Wiley, M., Kanehl, P., Baker, E., Niemala, S., and Stewart, P.M. 2003. Watershed, reach, and riparian influences on stream fish assemblages in the Northern Lakes and Forests Ecoregion, USA. Can. J. Fish. Aquat. Sci. 60: 491-505.

Wiley, M.J., Kohler, S.L., and Seelbach, P.W. 1997. Reconciling landscape and local views of aquatic communities: lessons from Michigan trout streams. Freshw. Biol. 37: 133-148.

Wiley, M.J., Seelbach, P.W., and Wherly, K.E. 2002. Regional ecological normalization using linear models: a meta-method for scaling stream assessment indicators. In Biological response signatures: indicator patterns using aquatic species. Edited by T.P. Simon. CRC Press, Boca Raton, Fla. pp. 201-224.

Wolter, P.T., Mladenoff, D.J., Host, G.E., and Crow, T.R. 1995. Improved forest classification in the northern Lake States using multi-temporal Landsat imagery. Photogramm. Eng. Remote Sens. 161: 1129-1143.

\section{Appendix A}

Table A1. Mean and range of in-stream habitat, water quality, riparian, and watershed conditions at second- and third-order streams sampled during 1997 and 1998 during the comparative watershed study.

\begin{tabular}{|c|c|c|c|c|}
\hline \multirow[b]{2}{*}{ Environmental variable } & \multicolumn{2}{|c|}{ Second-order sites (1997) } & \multicolumn{2}{|c|}{ Third-order sites (1998) } \\
\hline & Mean & Range & Mean & Range \\
\hline \multicolumn{5}{|l|}{ In-stream habitat variables } \\
\hline Stream width $(\mathrm{m})$ & 4.7 & $2.7-10.1$ & 7.3 & $2.7-16.7$ \\
\hline Bank-full width (m) & 10.5 & $4.8-20.2$ & 15.5 & $8.8-23.6$ \\
\hline Bank height (m) & 1.0 & $0.6-1.3$ & 1.3 & $0.7-2.0$ \\
\hline Bank erosion $(\%)$ & 35 & $2-68$ & 37 & $4-78$ \\
\hline Water depth (m) & 0.2 & $0.1-0.5$ & 0.3 & $0.1-0.6$ \\
\hline Thalweg depth (m) & 0.6 & $0.1-1.1$ & 0.8 & $0.4-1.3$ \\
\hline Flow $\left(\mathrm{m} \cdot \mathrm{s}^{-1}\right)$ & 0.05 & $0-0.2$ & 0.06 & $0-0.2$ \\
\hline Maximum flow $\left(\mathrm{m} \cdot \mathrm{s}^{-1}\right)$ & 0.2 & $0-0.4$ & 0.2 & $0-0.4$ \\
\hline \multicolumn{5}{|l|}{ Fish cover $(\%)$} \\
\hline Undercut banks & 1 & $0-4$ & 0.1 & $0-0.8$ \\
\hline Boulders & 10 & $0-32$ & 12 & $0-36$ \\
\hline Overhanging vegetation & 1 & $0-9$ & 1 & $0-5$ \\
\hline Submerged or floating aquatic vegetation & 0.1 & $0-2$ & 0.2 & $0-5$ \\
\hline Emergent aquatic vegetation & nd & nd & 0.2 & $0-3$ \\
\hline Woody debris & 3 & $0-13$ & 2 & $0-6$ \\
\hline Total & 16 & $7-35$ & 15 & $12-36$ \\
\hline
\end{tabular}


Table A1 (continued).

\begin{tabular}{|c|c|c|c|c|}
\hline \multirow[b]{2}{*}{ Environmental variable } & \multicolumn{2}{|c|}{ Second-order sites (1997) } & \multicolumn{2}{|c|}{ Third-order sites (1998) } \\
\hline & Mean & Range & Mean & Range \\
\hline No. of pieces of large wood $(>30 \mathrm{~cm})$ & 0.2 & $0-1.0$ & 0.1 & $0-0.5$ \\
\hline No. pieces medium wood $(10-30 \mathrm{~cm})$ & 1.2 & $0-3.2$ & 1.0 & $0-4.0$ \\
\hline Periphyton cover $(\%)$ & 64 & $0-100$ & 13 & $0-44$ \\
\hline Depth of fine sediments (m) & 0.1 & $0.01-0.3$ & 0.03 & $0-0.1$ \\
\hline Embeddedness $(\%)$ & 49 & $11-98$ & 32 & $1-56$ \\
\hline \multicolumn{5}{|l|}{ Substrate $(\%)$} \\
\hline Bedrock & 5 & $0-53$ & 2 & $0-32$ \\
\hline Boulder & 20 & $0-78$ & 11 & $0-60$ \\
\hline Cobble & 53 & 0-97 & 28 & $0-56$ \\
\hline Gravel & 57 & $0-95$ & 27 & $7-53$ \\
\hline Sand & 34 & $0-100$ & 27 & $0-87$ \\
\hline Silt & 4 & $0-49$ & 1 & $0-17$ \\
\hline Clay & 12 & $0-100$ & 4 & $0-32$ \\
\hline Detritus & 1 & $0-13$ & 1 & $0-3$ \\
\hline Other & 2 & $0-14$ & nd & nd \\
\hline Fine sediments $(\%)$ & 28 & 0-97 & 32 & $0-92$ \\
\hline Riffle area $(\%)$ & 25 & $0-60$ & 19 & $0-63$ \\
\hline Pool area $(\%)$ & 42 & $0-100$ & 48 & $14-88$ \\
\hline Width to depth ratio & 19.2 & $5.9-44.8$ & 18.0 & $7.9-27.6$ \\
\hline Riffle to riffle ratio & 8.0 & $1.8-43.3$ & 8.1 & $1.4-33.6$ \\
\hline Bend to bend ratio & 10.6 & $0.7-36.2$ & 9.8 & $0.6-65.7$ \\
\hline Reach length $(\mathrm{m})$ & 185 & $150-354$ & 264 & $156-500$ \\
\hline Habitat complexity (seconds fished per square metre) & 1.7 & $0.8-2.8$ & 1.5 & $0.6-3.1$ \\
\hline Rocky substrate $(\%)$ & 71 & $0-100$ & 67 & $7-100$ \\
\hline \multicolumn{5}{|l|}{ Water quality variables } \\
\hline Conductivity $\left(\mu \mathrm{S} \cdot \mathrm{cm}^{-1}\right)$ & 137 & $44-310$ & 163 & $31-363$ \\
\hline Minimum conductivity & 78 & $8-211$ & 148 & $29-335$ \\
\hline Maximum conductivity & 198 & $68-488$ & 175 & $32-407$ \\
\hline Dissolved oxygen $\left(\mathrm{mg} \cdot \mathrm{L}^{-1}\right)$ & 9.5 & $7.2-11.0$ & 8.4 & $0.8-12.2$ \\
\hline Minimum dissolved oxygen & 8.3 & $5.1-10.4$ & 7.4 & $0.8-11.0$ \\
\hline Maximum dissolved oxygen & 11.1 & $8.9-15.8$ & 9.7 & $0.8-17.7$ \\
\hline $\mathrm{pH}$ & 7.5 & $6.8-8.0$ & 7.6 & $6.6-8.4$ \\
\hline Minimum $\mathrm{pH}$ & 6.7 & $6.1-7.4$ & 7.3 & $5.3-8.0$ \\
\hline Maximum pH & 8.0 & $7.0-8.6$ & 7.9 & $6.7-8.7$ \\
\hline Turbidity (NTU) & 33 & $2-424$ & 12 & $0.5-155$ \\
\hline Minimum turbidity & 7 & $1-67$ & 6 & $0.3-55$ \\
\hline Maximum turbidity & 137 & $4-2117$ & 21 & $0.8-283$ \\
\hline \multicolumn{5}{|l|}{ Water temperature $\left({ }^{\circ} \mathrm{C}\right)$} \\
\hline 7-day average maximum & 18.4 & $12.0-24.9$ & 21.2 & $12.9-24.1$ \\
\hline 21-day average maximum & 17.6 & $11.7-22.0$ & 20.2 & $12.5-23.3$ \\
\hline 28 -day average maximum & 17.3 & $11.6-22.0$ & 19.9 & $12.3-22.5$ \\
\hline 1-day maximum average & 20.5 & $13.7-25.2$ & 22.8 & $14.0-26.4$ \\
\hline \multicolumn{5}{|l|}{ Riparian variables } \\
\hline \multicolumn{5}{|l|}{ Riparian land cover $(\%)$} \\
\hline Meadow & 24 & $1.5-72$ & 21 & $2-64$ \\
\hline Rock & 3 & $0-17$ & 2 & $0-22$ \\
\hline Shrubs & 42 & $14-80$ & 34 & $14-80$ \\
\hline Forest & 29 & $4-61$ & 41 & $0.4-84$ \\
\hline Wetland & 0.3 & $0-5$ & 0.4 & $0-5$ \\
\hline Other & 2 & $0-17$ & nd & nd \\
\hline Riparian buffer width (m) & 56.9 & $39.9-60.0$ & 57.5 & $48.4-60.0$ \\
\hline Floodplain width $(\mathrm{m})$ & 27.4 & $10.5-60.7$ & 54.2 & $23.3-100.0$ \\
\hline Riparian coniferous trees $(\%)$ & 21 & $0-49$ & 24 & $0-65$ \\
\hline Riparian shade $(\%)$ & 50 & $27-68$ & 40 & $12-58$ \\
\hline In-stream shade $(\%)$ & 29 & $6-49$ & 12 & $1-29$ \\
\hline Canopy angle (degrees) & 47.4 & $8.9-94.6$ & 79.7 & $38.1-145.4$ \\
\hline
\end{tabular}


Table A1 (concluded).

\begin{tabular}{|c|c|c|c|c|}
\hline \multirow[b]{2}{*}{ Environmental variable } & \multicolumn{2}{|c|}{ Second-order sites (1997) } & \multicolumn{2}{|c|}{ Third-order sites (1998) } \\
\hline & Mean & Range & Mean & Range \\
\hline \multicolumn{5}{|l|}{ Watershed variables } \\
\hline Storage ( $\%$ lake and wetland area) & 18 & $1-50$ & 21 & $1-44$ \\
\hline Mature forest cover $(\%)$ & 53 & $26-88$ & 50 & $25-81$ \\
\hline Recently logged (\%) & 15 & $2-38$ & 11 & $2-27$ \\
\hline Watershed area $\left(\mathrm{km}^{2}\right)$ & 30.4 & $6.9-96.6$ & 99.1 & $21.9-197.2$ \\
\hline Watershed perimeter $(\mathrm{km})$ & 31.3 & $15.5-69.8$ & 59.9 & $24.1-97.2$ \\
\hline Channel gradient $\left(\mathrm{m} \cdot \mathrm{km}^{-1}\right)$ & 10.7 & $0.9-30.1$ & 17.6 & $1.2-29.0$ \\
\hline
\end{tabular}

\section{Reference}

Simonson, T.D., Lyons, J., and Kanehl, P.D. 1994. Quantifying fish habitat in streams: transect spacing, sample size, and a proposed framework. N. Am. J. Fish. Manag. 14: 607-615. 